Atmos. Chem. Phys., 13, 4529-4541, 2013

www.atmos-chem-phys.net/13/4529/2013/

doi:10.5194/acp-13-4529-2013

(c) Author(s) 2013. CC Attribution 3.0 License.

\title{
ACE-FTS observations of pyrogenic trace species in boreal biomass burning plumes during BORTAS
}

\author{
K. A. Tereszchuk ${ }^{1}$, G. González Abad ${ }^{1,4}$, C. Clerbaux ${ }^{2,3}$, J. Hadji-Lazaro ${ }^{3}$, D. Hurtmans ${ }^{3}$, P.-F. Coheur ${ }^{3}$, and \\ P. F. Bernath ${ }^{1,5}$ \\ ${ }^{1}$ Department of Chemistry, University of York, Heslington, York YO10 5DD, UK \\ ${ }^{2}$ UPMC Univ. Paris 06, Université Versailles St-Quentin, CNRS/INSU, LATMOS-IPSL, Paris, France \\ ${ }^{3}$ Spectroscopie de l'Atmosphère, Service de Chimie Quantique et de Photophysique, Université Libre de Bruxelles (U.L.B.), \\ Brussels, Belgium \\ ${ }^{4}$ Harvard-Smithsonian Center for Astrophysics, Atomic and Molecular Physics Division, Cambridge MA 02138, USA \\ ${ }^{5}$ Department of Chemistry \& Biochemistry, Old Dominion University, Norfolk VA 23529-0126, USA
}

Correspondence to: K. A. Tereszchuk (keith.tereszchuk@york.ac.uk)

Received: 26 November 2012 - Published in Atmos. Chem. Phys. Discuss.: 10 December 2012

Revised: 21 March 2013 - Accepted: 12 April 2013 - Published: 2 May 2013

\begin{abstract}
To further our understanding of the effects of biomass burning emissions on atmospheric composition, the BORTAS campaign (BOReal forest fires on Tropospheric oxidants over the Atlantic using Aircraft and Satellites) was conducted on 12 July to 3 August 2011 during the boreal forest fire season in Canada. The simultaneous aerial, ground and satellite measurement campaign sought to record instances of boreal biomass burning to measure the tropospheric volume mixing ratios (VMRs) of short- and longlived trace molecular species from biomass burning emissions. The goal was to investigate the connection between the composition and the distribution of these pyrogenic outflows and their resulting perturbation to atmospheric chemistry, with particular focus on oxidant species to determine the overall impact on the oxidizing capacity of the free troposphere.

Measurements of pyrogenic trace species in boreal biomass burning plumes were made by the Atmospheric Chemistry Experiment Fourier Transform Spectrometer (ACE-FTS) onboard the Canadian Space Agency (CSA) SCISAT-1 satellite during the BORTAS campaign. Even though biomass burning emissions are typically confined to the boundary layer, outflows are often injected into the upper troposphere by isolated convection and fire-related convective processes, thus allowing space-borne instruments to measure these pyrogenic outflows. An extensive set of 14 molecules $-\mathrm{CH}_{3} \mathrm{OH}, \mathrm{C}_{2} \mathrm{H}_{2}, \mathrm{C}_{2} \mathrm{H}_{6}, \mathrm{C}_{3} \mathrm{H}_{6} \mathrm{O}, \mathrm{CO}, \mathrm{HCN}$,
\end{abstract}

$\mathrm{HCOOH}, \mathrm{HNO}_{3}, \mathrm{H}_{2} \mathrm{CO}, \mathrm{NO}, \mathrm{NO}_{2}, \mathrm{OCS}, \mathrm{O}_{3}$, and PAN have been analysed. Included in this analysis is the calculation of age-dependent sets of enhancement ratios for each of the species originating from fires in North America (Canada, Alaska) and Siberia for a period of up to 7 days. Ratio values for the shorter lived primary pyrogenic species decrease over time primarily due to oxidation by the $\mathrm{OH}$ radical as the plume ages and values for longer lived species such as $\mathrm{HCN}$ and $\mathrm{C}_{2} \mathrm{H}_{6}$ remain relatively unchanged. Increasing negative values are observed for the oxidant species, including $\mathrm{O}_{3}$, indicating a destruction process in the plume as it ages such that concentrations of the oxidant species have dropped below their off-plume values.

Results from previous campaigns have indicated that values for the molar ratios of $\Delta \mathrm{O}_{3} / \Delta \mathrm{CO}$ obtained from the measurements of the pyrogenic outflow from boreal fires are highly variable and range from negative to positive, irrespective of plume age. This variability has been attributed to pollution effects where the pyrogenic outflows have mixed with either local urban $\mathrm{NO}_{\mathrm{x}}$ emissions or pyrogenic emissions from the long-range transport of older plumes, thus affecting the production of $\mathrm{O}_{3}$ within the plumes. The results from this study have identified another potential cause of the variability in $\mathrm{O}_{3}$ concentrations observed in the measurements of biomass burning emissions, where evidence of stratosphere-troposphere exchange due to the pyroconvective updrafts from fires has been identified. Perturbations 
caused by the lofted emissions in these fire-aided convective processes may result in the intrusion of stratospheric air masses into the free troposphere and subsequent mixing of stratospheric $\mathrm{O}_{3}$ into the pyrogenic outflows causing fluctuations in observed $\Delta \mathrm{O}_{3} / \Delta \mathrm{CO}$ molar ratios.

\section{Introduction}

For nearly $40 \mathrm{yr}$ the scientific community has studied the emission of trace constituents from different types of fuel and associated atmospheric concentrations, but our knowledge remains incomplete, reflecting the heterogeneous and stochastic nature of this process. Biomass burning has an important role in determining the composition of the Earth's surface and atmosphere, and in some regions emissions to the atmosphere rival those from fossil fuel combustion. Spaceborne observations of land surface and tropospheric composition provided the first glimpse of the large-scale impact of burning in the global troposphere, where biomass burning events represent an important source of gases and particles released into the atmosphere (Crutzen et al., 1979; Crutzen and Andreae, 1990; Andreae and Merlet, 2001).

The emissions from biomass burning are recognized to be a major contributor of chemically active trace gases and aerosols. Wildfires can alter air quality on regional to hemispheric scales, and are an important component of the climate system. A wide variety of pyrogenic species are emitted, including carbon dioxide $\left(\mathrm{CO}_{2}\right)$, carbon monoxide $(\mathrm{CO})$, and hydrogen cyanide $(\mathrm{HCN})$, plus numerous volatile organic hydrocarbons (VOCs), oxygenated volatile organic compounds (OVOCs) as well as nitrogen, sulfur, and halogen-containing species, which are transformed by photochemical processes occurring during the first few hours in the plume. These molecules significantly alter the distribution of tropospheric ozone $\left(\mathrm{O}_{3}\right)$ and influence the oxidizing capacity of the atmosphere (Coheur et al., 2007).

The goal of this work is to report and interpret the tropospheric mixing ratios of short and long-lived trace molecular species from boreal biomass burning emissions obtained from infrared solar occultation measurements made with the Atmospheric Chemistry Experiment Fourier Transform Spectrometer (ACE-FTS) instrument on the Canadian Space Agency (CSA) SCISAT-1 satellite (Bernath et al., 2005), and serves as an integral part of the BORTAS project (BOReal forest fires on Tropospheric oxidants over the Atlantic using Aircraft and Satellites) (http://www.geos.ed.ac.uk/research/eochem/bortas/).

With the FAAM BAe 146 Atmospheric Research Aircraft (ARA) and ground stations based primarily in eastern and maritime Canada, one of the primary goals of the BORTAS measurement campaign (Palmer et al., 2012) was to sample aged boreal biomass burning plumes from the longrange transport of pyrogenic outflows originating from the fire activity that is prevalent in Siberia, Alaska, and northwestern Canada during the months of July and August. These outflows track from west to east across mainland Canada and eventually make their way to the North Atlantic. The data obtained from BORTAS would serve to complement the data acquired during the 2008 NASA Arctic Research of the Composition of the Troposphere from Aircraft and Satellites (ARCTAS) campaign (Hornbrook et al., 2011; Singh et al., 2010), which focused predominantly on measurements of nascent and young boreal plumes sampled close to the emission source.

Tracer-tracer correlation calculations are carried out between known pyrogenic species to derive sets of agedependent enhancement ratios (Lefer et al., 1994), i.e. normalized excess mixing ratios (Hobbs et al., 2003). Chemical transport models (CTMs) can then be used to study the aging and chemical evolution of boreal biomass burning emissions to quantify the impact on the global troposphere. In addition, the data can be employed to complement the aircraft and ground measurements made during the BORTAS campaign. The main benefit of satellite measurements is that they can provide a global perspective; observations can be made of the long-range transport of pyrogenic outflows from the source, where instrument aircraft and ground stations have a limited range.

This work is also part of an in-depth study being conducted in an attempt to characterize biomass burning emissions remotely by considering criteria such as age and type of biomass material to further our understanding of the impact of biomass burning on atmospheric chemistry. Included in this study will be the addition of new VOC and OVOC species including PAN (Allen et al., 2005) retrieved by ACE-FTS to aid in plume differentiation and characterization of biomass burning emissions in the upper troposphere and lower stratosphere (UTLS).

ACE-FTS is a high-resolution $\left(0.02 \mathrm{~cm}^{-1}\right)$ Fourier transform spectrometer used to record limb spectra of the Earth's atmosphere using the solar occultation technique. ACE-FTS uses the Sun as a light source to record transmittance spectra during sunrise and sunset occultations when the instrument peers through the atmosphere as the satellite rises and sets in its orbit of the Earth. The resulting spectra, with high signal-to-noise ratios, are recorded through long atmospheric limb paths ( $\sim 300 \mathrm{~km}$ effective length), thus providing an adequate detection threshold for trace species. ACE-FTS has an excellent vertical resolution of about $2-3 \mathrm{~km}$ in the troposphere and can measure up to 30 occultations (i.e. sunrise and sunset events viewed from the orbiting satellite) per day, with each occultation sampling the atmosphere from $150 \mathrm{~km}$ down to the cloud tops (or $5 \mathrm{~km}$ in the absence of clouds). The locations of ACE-FTS occultations are dictated by the $650 \mathrm{~km}$ altitude, $74^{\circ}$ inclination, circular orbit of SCISAT-1 and the relative position of the Sun. Over the course of a year, ACE-FTS records atmospheric spectra over a large portion of the globe (Bernath et al., 2005). 
The instrument has a wide spectral range that covers a region from 750 to $4400 \mathrm{~cm}^{-1}$, allowing for the retrieval of numerous molecular species. Through the version 3.0 dataset (http://www.ace.uwaterloo.ca), retrievals are made for over 40 species as well as their isotopologues, more than a dozen of which are found in biomass burning emissions. With the large suite of molecular species available, and providing near-global coverage, ACE-FTS is currently the most suitable remote-sensing instrument for this type of detailed investigation.

A number of studies have been previously conducted using remote measurements of biomass burning emissions from ACE-FTS (Rinsland et al., 2005, 2007; Coheur et al., 2007) as well as other space-borne instruments (Coheur et al., 2009; Glatthor et al., 2009; Torres et al., 2009; Turquety et al., 2009). Rinsland et al. (2005) first explored the possibility of using ACE-FTS to study the emission of longer lived primary pyrogenic species and their long-range transport to establish the effectiveness of ACE-FTS in measuring the emission of trace species from biomass burning. This work was followed up by a more extensive analysis of the elevated volume mixing ratios (VMRs) for numerous species emitted from young boreal plumes, deriving emission ratios and calculating tracer-tracer correlation coefficients to demonstrate their enhancement (Rinsland et al., 2007). The results from these preliminary studies precipitated interest in the retrieval of additional pyrogenic organic species such as ethene $\left(\mathrm{C}_{2} \mathrm{H}_{4}\right)$, propyne $\left(\mathrm{C}_{3} \mathrm{H}_{4}\right)$, formaldehyde $\left(\mathrm{H}_{2} \mathrm{CO}\right)$, acetone $\left(\mathrm{C}_{3} \mathrm{H}_{6} \mathrm{O}\right)$, and peroxyacetylnitrate - abbreviated as PAN $\left(\mathrm{CH}_{3} \mathrm{COO}_{2} \mathrm{NO}_{2}\right)$ - and were the first reported detections of these species using infrared solar occultation spectroscopy from satellites (Coheur et al., 2007). Most recently, ACE-FTS was successfully used to demonstrate its ability to characterize biomass burning emissions from distinct fuel types and follow their chemical evolution as the plumes age in the troposphere (Tereszchuk et al., 2011). The results of this investigation indicated that space-borne measurements of biomass burning emissions from different ecosystems can be differentiated by their unique chemical composition and that the formation and destruction of pyrogenic trace species within biomass burning plumes can be monitored, thus forming the basis for this more extensive work.

\section{ACE-FTS detection of boreal biomass burning emissions}

\subsection{Plume identification}

In past studies using ACE-FTS to identify measurements of biomass burning plumes, carbon monoxide $(\mathrm{CO})$ was the molecular species employed to find occultations that have sampled pyrogenic emissions through enhanced concentrations of $\mathrm{CO}$ relative to the background. $\mathrm{CO}$ is a well-known primary pyrogenic species with an atmospheric lifetime of

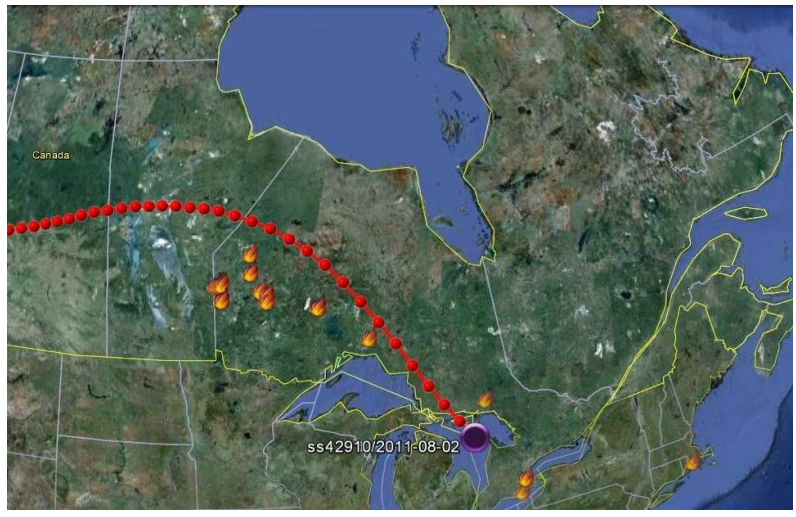

Fig. 1. An example output of the trajectory data obtained using HYSPLIT. The 3-day back trajectory calculated from occultation ss42910 (purple icon), measured on 2 August 2011, is displayed in Google ${ }^{\mathrm{TM}}$ Earth with the instances of fire activity observed by MODIS over North America on 1 August 2011. Spatial and temporal coincidences of the back trajectory confirm the emission source of the ACE-FTS measurement of enhanced HCN to be the outflow from the boreal fires in western Ontario. The measurement is of a young plume that is $<24 \mathrm{~h}$ in age.

$\sim 2$ months in the free troposphere, but due to it being also emitted from numerous anthropogenic sources, another longlived species that is more specific to biomass burning was chosen for plume detection. Hydrogen cyanide (HCN) has a life time of $\sim 5$ months and is emitted almost entirely from biomass and biofuel combustion. Typical background concentrations for $\mathrm{HCN}$ in the free troposphere have been determined to be $0.225-0.250 \mathrm{ppb}$ (Li et al., 2003; Singh et al., 2003). In this work occultations containing altitude profiles with enhanced tropospheric VMRs of $\mathrm{HCN} \geq 0.30$ ppbv are deemed measurements of biomass burning emissions.

\subsection{ACE-FTS data processing}

Version 3.0 of the ACE-FTS dataset, in which the retrieved data have been interpolated onto a $1 \mathrm{~km}$ altitude grid, was used for this work. An overview of the retrieval method, error budget for retrieved VMRs and the piecewise quadratic interpolation of the data are outlined by Boone et al. (2005). To identify measurements made in the free troposphere, values for heights of the thermal tropopause were obtained from derived meteorological products (DMPs) that are produced using the ACE-FTS version 3.0 dataset (Manney et al., 2007); all measurements that were recorded above the altitude corresponding to the tropopause in each occultation were identified so that they could be excluded during the calculation of the enhancement ratios. The data obtained from below the tropopause was then filtered by calculating the median VMR values for each altitude on the $1 \mathrm{~km}$ grid for each of the trace species to be studied. Retrievals containing measurements with molecular VMRs values that were less than 
$10 \%$ of the median value at a given altitude were rejected as this normally indicates retrieval failure. The primary cause of retrieval failure is due to cloud contamination. ACE-FTS can effectively make measurements through thin clouds, but measurements of the free troposphere which contain thick clouds in the field of view (FOV) of the instrument can cause the retrieval to fail at these altitudes and the outcome of the retrieval is a deviation of the vertical profile to unrealistically low and even negative values for the VMR of a given molecular species. The median filtering eliminates all measurements within each occultation that contain these large deviations to assure that the measurements being used are only those where the troposphere is cloudless during the time of measurement. The remainder of the data was then filtered to remove measurements containing unrealistically large retrieval errors as they indicate a failed convergence in the retrieval. To do this the median absolute deviation (MAD) was calculated from the associated retrieval errors; if the retrieval error at a given altitude was greater than 100 times the MAD value calculated from the dataset, they too were rejected. Having filtered the data for any erroneous measurements, those occultations which contained $\mathrm{HCN}$ altitude profiles with VMRs of $\mathrm{HCN} \geq 0.30 \mathrm{ppbv}$ were deemed measurements of biomass burning plumes and measurements with VMRs of $\mathrm{HCN} \leq 0.25 \mathrm{ppbv}$ treated as non-biomass burning or off-plume measurements.

\subsection{Determination of emission sources}

Once ACE-FTS occultations containing measurements of biomass burning emissions were identified, the origins of plumes measured from instances of boreal forest fires were determined. To do this the combined daily fire data recorded by the Moderate-Resolution Imaging Spectroradiometer (MODIS) instruments onboard the Aqua and Terra satellites were obtained from the Fire Information for Resource Management System (FIRMS) Archive Download Tool (http://earthdata.nasa.gov/data/nrt-data/firms/active-fire-data) available through NASA's Earth Observing System Data and Information System (EOSDIS). The MODIS fire counts were used concertedly with back trajectory calculations generated by the Hybrid Single-Particle Lagrangian Integrated Trajectory (HYSPLIT) (Draxler and Rolph, 2003) model to locate the sources of boreal biomass burning measured by ACE-FTS. The altitudes corresponding to the maximum value for the VMR of HCN in the ACE-FTS retrieval profiles were used as the starting point in HYSPLIT to calculate back trajectories of the air mass from the point of measurement to recorded instances of boreal fires. In this way the relative age of the plume can be determined with an accuracy of \pm 1 day. An example of plume identification determined from the calculated back trajectories made with HYSPLIT is seen in Fig. 1, where the outflow originating from large boreal fires burning in western Ontario (2 August 2011) is measured over Lake Huron/Georgian Bay a few hours

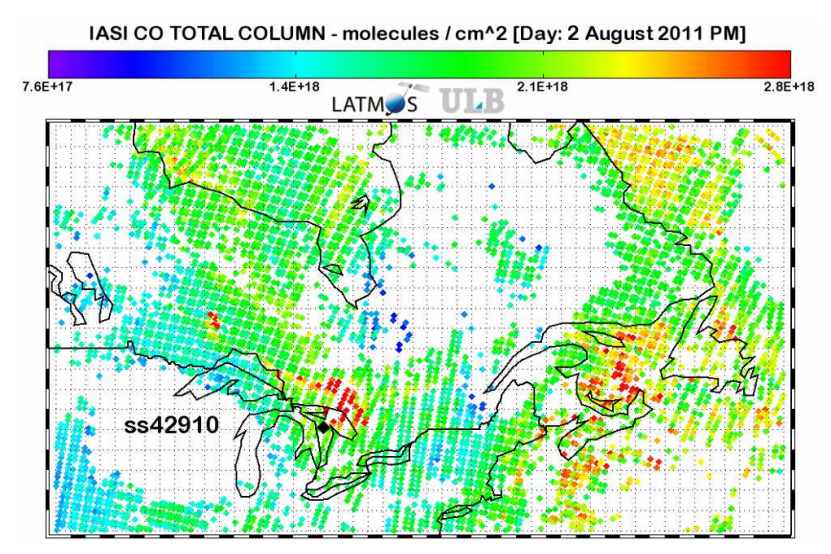

Fig. 2. IASI CO total column data for the evening orbit over North America on 2 August 2011. The figure clearly shows the biomass burning outflow from the fires in western Ontario. The plume, sampled during occultation ss42910 over Lake Huron/Georgian Bay (black diamond), is clearly visible and the path of the outflow emulates the HYSPLIT back trajectory where the plume follows a southeasterly path from the source over the Great Lakes towards southern Ontario. The elevated CO observed over southern Quebec and Maritime Canada is coming from a mixture of older plumes originating from the fires in western Ontario and also concurrent fire activity that was occurring in the Northwest Territories toward the end of July and the beginning of August.

later by ACE-FTS sunset occultation ss42910 (measurement location represented by the purple icon). It is understood that by employing this technique to identify plume sources, there is some uncertainty in the locations of ground-level fires, and thus the associated plume age, due to the fact that fires are often not detected as hotspots and can inject smoke at a variety of initial altitudes. The problem of undersampling was outlined by Stubenrauch et al. (2010), demonstrating that the climatological cloud cover over Canada during the summer months can be quite high - over $50 \%$ in western Canada during the month of July, the height of fire activity for that region. The inability of MODIS to penetrate heavy cloud cover suggests that many small fires can potentially go undetected by active fire detection and sources could be erroneously assigned when relying on hotspots alone. To avoid any ambiguity in locations of these sporadic, individual hotspots, the ACE-FTS measurements used in this work are from the outflows of substantial biomass burning events, such as those observed in western Ontario during the BORTAS campaign: occurrences of continued fire activity in the same geographical region over an extended period time (days to weeks), where numerous hotspots repeatedly appear, on a daily basis, within the same geographical area. Unfortunately, there still exists the caveat that emissions from undetected fires may have a minor contribution to the plumes being sampled by ACE-FTS and thus introduce some uncertainty in the measurement. 
Google ${ }^{\mathrm{TM}}$ Earth was used as a visualization tool to bring ACE-FTS occultations, the MODIS fire data and HYSPLIT trajectories together in order to facilitate the determination of the sources of biomass burning plumes. Scripts were written in Keyhole Markup Language (KML) in order to import the locations of ACE-FTS occultations and MODIS fire data into Google ${ }^{\mathrm{TM}}$ Earth along with the air mass trajectories from HYSPLIT, which conveniently provides the option for output into the KML format. Visual inspection of the burn region was also done to assist in verifying the type of biomass material that is being burned. The near-real-time Level2 imager data from the MODIS Rapid Response System (http://rapidfire.sci.gsfc.nasa.gov/realtime/?calendar), which contains the daily MODIS hotspots mapped onto surface images of the Earth, was used to identify the burned area to confirm that only biomass burning from boreal forests is contributing to the pyrogenic emissions measured by ACE-FTS.

Since the HYSPLIT model can only serve to give a general indication of the direction of the movement of air masses at a given time, to further aid in the verification of the origin of biomass burning plumes, $\mathrm{CO}$ total column measurements from the Infrared Atmospheric Sounding Interferometer (IASI) onboard the MetOp-A satellite (George et al., 2009; Clerbaux et al., 2009) were used to track the outflow from boreal fires to validate the output calculated from the HYSPLIT back trajectories and to ensure that measurements made by ACE-FTS are from a single source and not a mixture of biomass burning outflows from different sources, which would produce erroneous values in the calculations of the age-dependent enhancement ratios. For example, plumes measured over the North Atlantic can come from a number of different sources since it is a region that corresponds to the confluence of numerous air masses. During the summer in the Northern Hemisphere, fire activity is prevalent in Canada, Alaska, Siberia, and California. As demonstrated during the spring (ARCTAS-A) and summer (ARCTAS-B, ARCTAS-CARB) campaigns in 2008 (Hornbrook et al., 2011; Singh et al., 2010), simultaneous outflows from each of these regions will often converge over Canada and the North Atlantic. The occurrence of any plume mixing from different sources would subsequently create uncertainty in the determination of plume origin and age. Figure. 2 shows an example of IASI CO total column measurements made over Canada on 2 August 2011. In it, a large biomass burning plume can be clearly seen near the Great Lakes originating from the fire activity occurring in western Ontario, which was measured by sunset occultation ss 42910 (measurement location represented by the black diamond). To track the outflows from multiple sources, animations were created using measurements from the morning and evening passes of IASI. The movements of these outflows were monitored over a period of days leading up to the time of the ACE-FTS measurement to determine the origin of the plumes and whether there is convergence from more than one source.
The IASI instrument is designed to measure the spectrum emitted by the Earth-atmosphere system in the TIR spectral range using nadir geometry and provides near-global coverage twice daily. Measurements are performed from MetOp-A in a Sun-synchronous polar orbit with a $98.7^{\circ}$ inclination to the equator at an altitude of $\sim 817 \mathrm{~km}$. The satellite ground track is at about 09:30 local time in the morning (and 21:30 in the evening). The time to complete an orbit is about 101 min, which implies that MetOp makes a little more than 14 orbits a day. The IASI instrument observes the Earth up to an angle of $48.3^{\circ}$ on both sides of the satellite track. This corresponds to $2 \times 15$ mirror positions and a swath of about $2 \times 1100 \mathrm{~km}$. Each instantaneous field of view $\left(3.3^{\circ} \times 3.3^{\circ}\right)$ is composed of $2 \times 2$ circular pixels, each corresponding to a $12 \mathrm{~km}$ diameter footprint on the ground at nadir.

The IASI CO total column data used in this work were obtained from the Ether Atmospheric Chemistry Data Centre (http://www.pole-ether.fr). It should be mentioned that IASI also played an integral role during the BORTAS aircraft campaign as near-real-time ( $<3 \mathrm{~h}$ after measurement) $\mathrm{CO}$ total column and vertical profile data were provided by the LATMOS research group (http://iasi-chem.aero.jussieu.fr/) and used for plume tracking and flight planning purposes.

\section{Enhancement ratios}

Tracer-CO correlation calculations were performed for 14 different molecular species to generate sets of age-dependent enhancement ratios. The majority of these species, such as $\mathrm{CH}_{3} \mathrm{OH}, \mathrm{C}_{2} \mathrm{H}_{2}, \mathrm{C}_{2} \mathrm{H}_{6}, \mathrm{HCN}, \mathrm{HCOOH}, \mathrm{HNO}_{3}, \mathrm{H}_{2} \mathrm{CO}$, and OCS are known pyrogenic, biomass burning species and have been previously studied with ACE-FTS. Data products for two new, reactive, pyrogenic species have recently been added to the version 3.0 dataset. These are peroxyacetyl nitrate $\left(\mathrm{CH}_{3} \mathrm{CO} \cdot \mathrm{O}_{2} \mathrm{NO}_{2}\right.$, abbreviated as PAN $)$ and acetone $\left(\mathrm{C}_{3} \mathrm{H}_{6} \mathrm{O}\right)$. In addition to these species, $\mathrm{NO}, \mathrm{NO}_{2}$ and $\mathrm{O}_{3}$ are also investigated to observe the effect of biomass burning emission on tropospheric oxidants. All occultations used for the calculations were recorded during the summer months of the Northern Hemisphere (JJA) in the 4 yr (2008-2011) leading up to and including the BORTAS campaign, where IASI CO data are available to confirm that the ACE-FTS measurements made are from a singular source and not from a mixture of multiple pyrogenic outflows.

Since the slope of the tracer-CO calculations are obtained using the measurements of trace species that are associated with the measurements of enhanced HCN ( $\geq 0.30 \mathrm{ppbv})$ in the biomass burning plumes, the slope value thus represents the enhancement ratio (Lefer et al., 1994) between the two pyrogenic species. The enhancement ratios can be used to determine trends in the plume photochemistry and can serve as constraints for CTMs to study the aging of biomass burning emissions in the free troposphere. Similar to the emission ratio (Andreae and Merlet, 2001), enhancement ratios 
Table 1. Age-dependent enhancement ratios for numerous pyrogenic species determined from the slope of the linear regression of tracer-CO calculations made from measurements of boreal biomass burning plumes originating from both North America (Canada, Alaska) and Siberia for a period of 7 days. The number of occultations $(n)$ used to calculate the enhancement ratio for each day is given in parenthesis. The reported error represents the 1-sigma uncertainty of the slope in the linear regression calculations.

\begin{tabular}{|c|c|c|c|c|c|c|c|}
\hline \multirow[b]{2}{*}{ Compound } & \multicolumn{7}{|c|}{ Boreal Enhancement Ratios (ppbv ppbv ${ }^{-1}$ ) } \\
\hline & $0-24 \mathrm{~h}$ & $24-48 \mathrm{~h}$ & $48-72 \mathrm{~h}$ & $72-96 \mathrm{~h}$ & $96-120 \mathrm{~h}$ & $120-144 \mathrm{~h}$ & $144-168 \mathrm{~h}$ \\
\hline North America & $(n=15)$ & $(n=14)$ & $(n=10)$ & $(n=16)$ & $(n=8)$ & $(n=7)$ & $(n=6)$ \\
\hline $\mathrm{CH}_{3} \mathrm{OH}$ & $(2.32 \pm 0.59) \times 10^{-2}$ & $(2.39 \pm 0.68) \times 10^{-2}$ & $(2.21 \pm 0.46) \times 10^{-2}$ & $(1.96 \pm 0.35) \times 10^{-2}$ & $(1.95 \pm 0.26) \times 10^{-2}$ & $(1.99 \pm 0.40) \times 10^{-2}$ & $(1.81 \pm 0.44) \times 10^{-2}$ \\
\hline $\mathrm{C}_{2} \mathrm{H}_{2}$ & $(3.32 \pm 0.33) \times 10^{-3}$ & $(2.53 \pm 0.44) \times 10^{-3}$ & $(1.56 \pm 0.18) \times 10^{-3}$ & $(1.10 \pm 0.12) \times 10^{-3}$ & $(0.98 \pm 0.19) \times 10^{-3}$ & $(0.88 \pm 0.15) \times 10^{-3}$ & $(0.68 \pm 0.61) \times 10^{-3}$ \\
\hline $\mathrm{C}_{2} \mathrm{H}_{6}$ & $(6.73 \pm 1.37) \times 10^{-3}$ & $(6.80 \pm 1.08) \times 10^{-3}$ & $(7.21 \pm 0.80) \times 10^{-3}$ & $(7.05 \pm 1.04) \times 10^{-3}$ & $(6.92 \pm 0.96) \times 10^{-3}$ & $(6.94 \pm 0.84) \times 10^{-3}$ & $(6.91 \pm 1.13) \times 10^{-3}$ \\
\hline $\mathrm{C}_{3} \mathrm{H}_{6} \mathrm{O}$ & $(1.68 \pm 0.25) \times 10^{-2}$ & $(1.25 \pm 0.99) \times 10^{-2}$ & $(1.20 \pm 0.42) \times 10^{-2}$ & $(0.94 \pm 0.19) \times 10^{-2}$ & $(0.88 \pm 0.27) \times 10^{-2}$ & $(0.86 \pm 0.18) \times 10^{-2}$ & $(0.57 \pm 0.76) \times 10^{-2}$ \\
\hline $\mathrm{HCN}$ & $(2.01 \pm 0.86) \times 10^{-3}$ & $(2.36 \pm 0.79) \times 10^{-3}$ & $(2.29 \pm 0.40) \times 10^{-3}$ & $(2.19 \pm 0.44) \times 10^{-3}$ & $(1.84 \pm 0.43) \times 10^{-3}$ & $(2.26 \pm 0.88) \times 10^{-3}$ & $(2.49 \pm 1.18) \times 10^{-3}$ \\
\hline $\mathrm{HCOOH}$ & $(4.91 \pm 0.96) \times 10^{-3}$ & $(4.25 \pm 0.82) \times 10^{-3}$ & $(3.79 \pm 0.66) \times 10^{-3}$ & $(3.34 \pm 0.42) \times 10^{-3}$ & $(1.40 \pm 0.44) \times 10^{-3}$ & $(1.46 \pm 0.49) \times 10^{-3}$ & $(1.25 \pm 1.15) \times 10^{-3}$ \\
\hline $\mathrm{HNO}_{3}$ & $(-0.34 \pm 0.16) \times 10^{-2}$ & $(-0.45 \pm 0.42) \times 10^{-2}$ & $(-0.54 \pm 0.15) \times 10^{-2}$ & $(-0.56 \pm 0.13) \times 10^{-2}$ & $(-0.65 \pm 0.22) \times 10^{-2}$ & $(-0.74 \pm 0.32) \times 10^{-2}$ & $(-1.29 \pm 0.19) \times 10^{-2}$ \\
\hline $\mathrm{H}_{2} \mathrm{CO}$ & $(1.33 \pm 0.28) \times 10^{-3}$ & $(1.14 \pm 0.33) \times 10^{-3}$ & $(0.85 \pm 0.29) \times 10^{-3}$ & $(0.72 \pm 0.16) \times 10^{-3}$ & $(0.36 \pm 0.22) \times 10^{-3}$ & $(0.22 \pm 0.14) \times 10^{-3}$ & $(0.21 \pm 0.50) \times 10^{-3}$ \\
\hline NO & $(3.85 \pm 1.19) \times 10^{-3}$ & $(2.72 \pm 0.45) \times 10^{-3}$ & $(1.94 \pm 0.72) \times 10^{-3}$ & $(1.70 \pm 1.38) \times 10^{-3}$ & $(0.71 \pm 0.98) \times 10^{-3}$ & $(0.62 \pm 0.17) \times 10^{-3}$ & $(0.80 \pm 0.41) \times 10^{-3}$ \\
\hline $\mathrm{NO}_{2}$ & $(-0.24 \pm 0.66) \times 10^{-3}$ & $(-0.51 \pm 0.36) \times 10^{-3}$ & $(-1.58 \pm 0.69) \times 10^{-3}$ & $(-1.69 \pm 0.29) \times 10^{-3}$ & $(-1.65 \pm 0.21) \times 10^{-3}$ & $(-1.34 \pm 0.80) \times 10^{-3}$ & $(-1.75 \pm 0.28) \times 10^{-3}$ \\
\hline OCS & $(1.28 \pm 0.29) \times 10^{-3}$ & $(1.21 \pm 0.33) \times 10^{-3}$ & $(1.21 \pm 0.19) \times 10^{-3}$ & $(0.92 \pm 0.22) \times 10^{-3}$ & $(0.79 \pm 0.46) \times 10^{-3}$ & $(0.30 \pm 0.16) \times 10^{-3}$ & $(0.14 \pm 0.35) \times 10^{-3}$ \\
\hline $\mathrm{O}_{3}$ & $-0.68 \pm 0.24$ & $-1.17 \pm 0.53$ & $-1.21 \pm 0.24$ & $-1.51 \pm 0.41$ & $-1.65 \pm 0.76$ & $-2.32 \pm 0.43$ & $-2.73 \pm 0.49$ \\
\hline PAN & $(5.53 \pm 0.69) \times 10^{-3}$ & $(4.69 \pm 0.93) \times 10^{-3}$ & $(4.33 \pm 0.63) \times 10^{-3}$ & $(4.49 \pm 0.97) \times 10^{-3}$ & $(3.45 \pm 0.12) \times 10^{-3}$ & $(3.61 \pm 0.54) \times 10^{-3}$ & $(3.45 \pm 0.16) \times 10^{-3}$ \\
\hline Siberia & $(n=20)$ & $(n=11)$ & $(n=9)$ & $(n=8)$ & $(n=8)$ & $(n=9)$ & $(n=3)$ \\
\hline $\mathrm{CH}_{3} \mathrm{OH}$ & $(4.28 \pm 0.43) \times 10^{-2}$ & $(3.91 \pm 0.37) \times 10^{-2}$ & $(3.52 \pm 0.44) \times 10^{-2}$ & $(3.16 \pm 0.58) \times 10^{-2}$ & $(3.24 \pm 0.55) \times 10^{-2}$ & $(3.18 \pm 0.84) \times 10^{-2}$ & $(2.13 \pm 1.10) \times 10^{-2}$ \\
\hline $\mathrm{C}_{2} \mathrm{H}_{2}$ & $(2.15 \pm 0.24) \times 10^{-3}$ & $(1.89 \pm 0.18) \times 10^{-3}$ & $(1.55 \pm 0.26) \times 10^{-3}$ & $(1.14 \pm 0.21) \times 10^{-3}$ & $(1.08 \pm 0.22) \times 10^{-3}$ & $(1.06 \pm 0.21) \times 10^{-3}$ & $(0.81 \pm 0.43) \times 10^{-3}$ \\
\hline $\mathrm{C}_{2} \mathrm{H}_{6}$ & $(6.09 \pm 1.01) \times 10^{-3}$ & $(5.88 \pm 0.91) \times 10^{-3}$ & $(6.07 \pm 0.73) \times 10^{-3}$ & $(6.29 \pm 1.84) \times 10^{-3}$ & $(6.30 \pm 0.89) \times 10^{-3}$ & $(6.12 \pm 1.44) \times 10^{-3}$ & $(6.94 \pm 2.34) \times 10^{-3}$ \\
\hline $\mathrm{C}_{3} \mathrm{H}_{6} \mathrm{O}$ & $(1.43 \pm 0.36) \times 10^{-2}$ & $(1.36 \pm 0.34) \times 10^{-2}$ & $(1.24 \pm 0.28) \times 10^{-2}$ & $(0.95 \pm 0.54) \times 10^{-2}$ & $(0.82 \pm 0.36) \times 10^{-2}$ & $(0.69 \pm 0.90) \times 10^{-2}$ & $\left(0.62 \pm 0.55 \times 10^{-2}\right.$ \\
\hline $\mathrm{HCN}$ & $(2.91 \pm 0.43) \times 10^{-3}$ & $(2.62 \pm 0.22) \times 10^{-3}$ & $(2.79 \pm 0.60) \times 10^{-3}$ & $(2.96 \pm 0.42) \times 10^{-3}$ & $(2.77 \pm 0.93) \times 10^{-3}$ & $(2.96 \pm 1.08) \times 10^{-3}$ & $(2.70 \pm 1.79) \times 10^{-3}$ \\
\hline $\mathrm{HCOOH}$ & $(6.41 \pm 0.75) \times 10^{-3}$ & $(4.15 \pm 0.47) \times 10^{-3}$ & $(3.27 \pm 0.74) \times 10^{-3}$ & $(2.33 \pm 0.45) \times 10^{-3}$ & $(1.45 \pm 1.02) \times 10^{-3}$ & $(1.34) \pm 1.27) \times 10^{-3}$ & $(0.77 \pm 1.81) \times 10^{-3}$ \\
\hline $\mathrm{HNO}_{3}$ & $(-0.37 \pm 0.12) \times 10^{-2}$ & $(-0.39 \pm 0.19) \times 10^{-2}$ & $(-0.44 \pm 0.53) \times 10^{-2}$ & $(-0.50 \pm 0.22) \times 10^{-2}$ & $(-0.57 \pm 0.30) \times 10^{-2}$ & $(-0.63 \pm 0.31) \times 10^{-2}$ & $(-1.30 \pm 0.08) \times 10^{-2}$ \\
\hline $\mathrm{H}_{2} \mathrm{CO}$ & $(2.54 \pm 0.28) \times 10^{-3}$ & $(1.07 \pm 0.16) \times 10^{-3}$ & $(1.22 \pm 0.59) \times 10^{-3}$ & $(0.92 \pm 0.23) \times 10^{-3}$ & $(0.33 \pm 0.18) \times 10^{-3}$ & $(0.27 \pm 0.20) \times 10^{-3}$ & $(0.18 \pm 0.52) \times 10^{-3}$ \\
\hline NO & $(3.19 \pm 0.56) \times 10^{-3}$ & $(1.72 \pm 0.36) \times 10^{-3}$ & $(2.77 \pm 0.95) \times 10^{-3}$ & $(1.12 \pm 0.58) \times 10^{-3}$ & $(1.17 \pm 0.50) \times 10^{-3}$ & $(0.57 \pm 0.09) \times 10^{-3}$ & $(0.55 \pm 0.86) \times 10^{-3}$ \\
\hline $\mathrm{NO}_{2}$ & $(-0.83 \pm 1.56) \times 10^{-3}$ & $(-0.87 \pm 1.24) \times 10^{-3}$ & $(-0.48 \pm 0.23) \times 10^{-3}$ & $(-2.04 \pm 1.39) \times 10^{-3}$ & $(-1.92 \pm 2.01) \times 10^{-3}$ & $(-2.14 \pm 0.58) \times 10^{-3}$ & $(-3.65 \pm 0.70) \times 10^{-3}$ \\
\hline OCS & $(7.41 \pm 2.01) \times 10^{-4}$ & $(8.46 \pm 1.07) \times 10^{-4}$ & $(5.94 \pm 2.44) \times 10^{-4}$ & $(5.92 \pm 2.16) \times 10^{-4}$ & $(5.58 \pm 2.32) \times 10^{-4}$ & $(1.77 \pm 1.87) \times 10^{-4}$ & $(0.68 \pm 1.45) \times 10^{-4}$ \\
\hline $\mathrm{O}_{3}$ & $-0.79 \pm 0.26$ & $-0.82 \pm 0.24$ & $-1.24 \pm 0.52$ & $-1.58 \pm 0.31$ & $-1.56 \pm 0.53$ & $-2.10 \pm 0.72$ & $-2.01 \pm 0.96$ \\
\hline PAN & $(2.63 \pm 0.67) \times 10^{-3}$ & $(4.42 \pm 0.89) \times 10^{-3}$ & $(3.78 \pm 0.64) \times 10^{-3}$ & $(3.34 \pm 0.72) \times 10^{-3}$ & $(3.80 \pm 0.94) \times 10^{-3}$ & $(2.82 \pm 1.71) \times 10^{-3}$ & $(2.69 \pm 2.21) \times 10^{-3}$ \\
\hline
\end{tabular}

are also calculated by dividing the excess trace species concentrations measured in a fire plume by the excess concentration of a simultaneously measured reference gas; $\mathrm{CO}$ is used as the reference species in this study. To obtain these excess concentrations, the ambient background concentrations must be subtracted from the values measured in the plume, i.e. $\Delta \mathrm{X} / \Delta \mathrm{CO}$ where $\Delta \mathrm{X}$ indicates the value of $\mathrm{X}_{\text {plume }}-\mathrm{X}_{\text {background }}$. Alternatively, the enhancement ratio can be determined as the linear regression slope of the species concentration versus the reference species, which is how the enhancement ratios were obtained in this work. The only difference between an emission ratio and enhancement ratio is that emission ratios are calculated from measurements at the time of emission, i.e. plumes with an age of zero. The enhancement ratio is the normalized excess mixing ratio (Hobbs et al., 2003) obtained from plumes which are nonnascent and have aged for a period of time.

Sets of age-dependent enhancement ratios (relative to $\mathrm{CO}$ ) for a number of trace species measured in boreal biomass burning plumes originating from North America (Canada and Alaska) and Siberia are listed in Table 1. The enhancement ratios are calculated using the combined data from individual measurements of plumes having the same relative age. On occasion, ACE-FTS will sample biomass burning plumes by making sequential measurements along the same pyro- genic outflow, as demonstrated in Tereszchuk et al. (2011); special consideration was not given to such coincidences and all occultation were treated as separate individual measurements in the calculation of the sets of enhancement ratios. The ages for the pyrogenic emission range from young plumes $(<24 \mathrm{~h}$ old $)$ to those which have aged for a period of up to 7 days. Measurements of older plumes become more difficult to obtain as the further away the outflow travels from the source, the more difficult it becomes to identify the origin with certainty, and there is increased likelihood that the outflow will have mixed with plumes being emitted from other fires that may be burning concurrently in other regions of the Northern Hemisphere, thus potentially introducing erroneous measurements in the calculation of the enhancement ratios.

In Table 1 the calculated molar ratios for $\mathrm{HCN}$ from the occultations containing vertical profiles of elevated $\mathrm{HCN}$ $(\geq 0.30 \mathrm{ppbv})$ are reported. Enhancements are observed in $\mathrm{HCN}$ and also for each of the other simultaneously retrieved pyrogenic species and are consistent with the elevated HCN VMRs values. As would be expected, the values for the shorter lived primary pyrogenic species decrease over time as these species are oxidized, mainly by reaction with $\mathrm{OH}$, as the plume ages, where values for longer lived species such as $\mathrm{HCN}$ and $\mathrm{C}_{2} \mathrm{H}_{6}$ remain relatively unchanged. Increasing negative values are observed for the oxidant species, which 
include $\mathrm{O}_{3}, \mathrm{NO}_{2}$ and $\mathrm{HNO}_{3}$, indicating that these species are undergoing a destruction process in the plume as it ages such that concentrations of the reactive species have dropped below their off-plume values. The enhancement ratios reported in Table 1 are similar to the results that were observed for boreal biomass burning emissions in a preliminary analysis that was done in the characterization of boreal biomass burning plumes using ACE-FTS by Tereszchuk et al. (2011), where a validation of the enhancement ratios was conducted by assuming that the enhancement ratios for the long-lived pyrogenic species can be utilized as the effective emission ratios for these species in the computation of their emission factors. These emission factors were then compared to the data published in the work by Akagi et al. (2011), which contains comprehensive sets of emission factors for biomass burning from numerous ecosystems and for domestic biomass burning. Included in the data set are the results obtained from the measurement of fresh Canadian smoke plumes recorded during ARCTAS-B (Simpson et al., 2011) and numerous other campaigns which sought to measure the emissions from boreal biomass burning. The emission factors obtained from the ACE-FTS measurements showed good agreement with the airborne emission factors calculated by Akagi et al. (2011), and were within the reported 1-sigma uncertainty.

As the biomass burning plumes age, the emitted gaseous pyrogenic species within it react and chemical transformations of these primary pyrogenic species take place leading to the formation of secondary species. Of these secondary species formed in aged plumes, $\mathrm{O}_{3}$ and $\mathrm{HNO}_{3}$ are particularly important. $\mathrm{HNO}_{3}$ is mainly formed by $\mathrm{OH}$-induced conversion of $\mathrm{NO}_{2}$, which results from rapid conversion of primary pyrogenic $\mathrm{NO} . \mathrm{NO}_{2}$ is also an important precursor to PAN which forms within a few hours. At low temperatures in the free troposphere, and in the presence of co-emitted $\mathrm{NH}_{3}$, $\mathrm{HNO}_{3}$ will quickly convert to ammonium nitrate $\left(\mathrm{NH}_{4} \mathrm{NO}_{3}\right)$ (Yokelson et al., 2009; Alvarado et al., 2010). At night, $\mathrm{NO}_{2}$ $+\mathrm{O}_{3}$ can make $\mathrm{NO}_{3}$ and $\mathrm{NO}_{2}+\mathrm{NO}_{3}$ can make $\mathrm{N}_{2} \mathrm{O}_{5}$, which can hydrolyse to make $\mathrm{HNO}_{3}$. If PAN or alkyl nitrates form in the plume, warming of the plume can cause decomposition and release some $\mathrm{NO}_{2}$ in the aged plume as a secondary product. Organics emitted from biomass burning lead to the formation of secondary $\mathrm{O}_{3}$, an important atmospheric oxidant and a precursor of $\mathrm{OH}$ radicals (Fiedler et al., 2009; Akagi et al., 2011). It is well known that reactions with the hydroxyl radical $(\mathrm{OH})$, the dominant oxidizing chemical in the atmosphere, drive atmospheric oxidation through reactions with species emitted from the Earth's surface. Many of these molecules lead to the chemical production of tropospheric $\mathrm{O}_{3}$ and other reactive trace gases (Rinsland et al., 2005).

\section{$4 \mathrm{O}_{3}$ production in boreal biomass burning}

That being said there is currently a great deal of debate surrounding the influence of forest fires on $\mathrm{O}_{3}$ production and

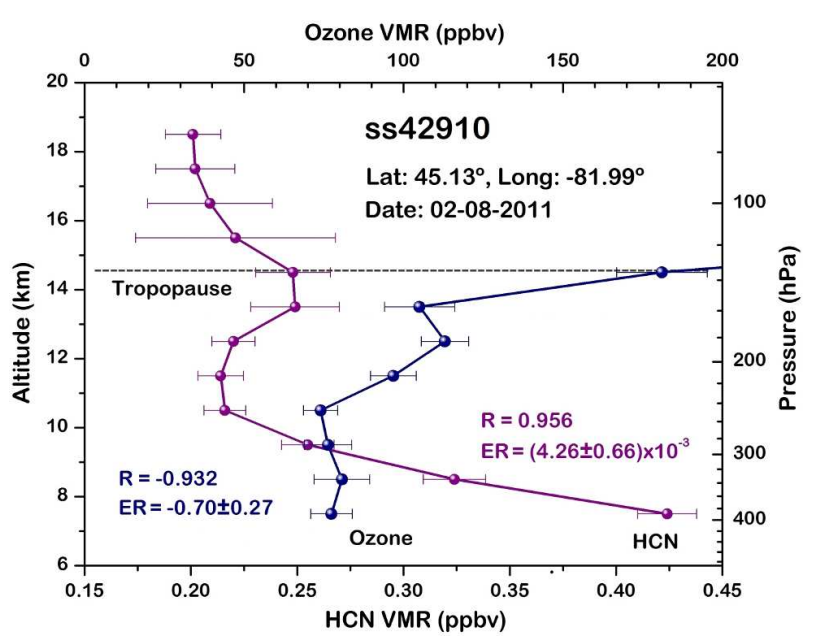

Fig. 3. ACE-FTS VMR profiles for $\mathrm{HCN}$ and $\mathrm{O}_{3}$ recorded from a young boreal plume (ss42910). Enhancements in the HCN VMRs occur below $10.5 \mathrm{~km}$ as the instrument records through the top of the pyrogenic outflow. Within the plume, $\mathrm{O}_{3}$ VMRs drop to $\sim 25 \%$ of their off-plume values, indicating a destruction process is occurring. The high negative correlation $(-0.932)$ and negative enhancement ratio $(-0.70 \pm 0.27)$ for $\mathrm{O}_{3}$ confirm this observation.

whether it is generated in boreal biomass burning plumes. The increasingly negative enhancement ratios for $\mathrm{O}_{3}$ in Table 1 indicate that it undergoes a destruction process within the plume in the first few days, the net decrease in concentration is most likely dominated by oxidation reactions with numerous short-lived primary pyrogenic species within the young plumes. It was also noted by Alvarado et al. (2010) that there was very little clear evidence for $\mathrm{O}_{3}$ formation in the young boreal plumes measured during ARCTAS-B in either aircraft or satellite observations and suggested that this was due to $40 \%$ of the $\mathrm{NO}_{\mathrm{x}}$ from the fires being converted to PAN within a few hours of emission, thus limiting the immediate reactivity of the plume.

An in-depth review of the production of $\mathrm{O}_{3}$ in wildfires was recently published by Jaffe and Wigder (2012). In it a summary of values for $\Delta \mathrm{O}_{3} / \Delta \mathrm{CO}$ obtained from numerous campaigns are tabulated in order of plume age. Values obtained from the measurements of the pyrogenic outflow from boreal fires are highly variable and range from negative to positive, irrespective of plume age. According to Jaffe and Wigder (2012), this variability is due to the interplay of numerous factors including fire emissions, efficiency of combustion, chemical and photochemical reactions, aerosol effects on chemistry and radiation, and local and downwind meteorological patterns. One important factor, in particular, is due to pollution interferences. Studies have demonstrated that there are $\mathrm{O}_{3}$ enhancements in wildfire plumes that have mixed with urban $\mathrm{NO}_{\mathrm{x}}$ emissions (Jaffe and Wigder, 2012; Singh et al., 2010). In a study of Arctic wildfire plumes, Singh et al. (2010) found molar ratios of 


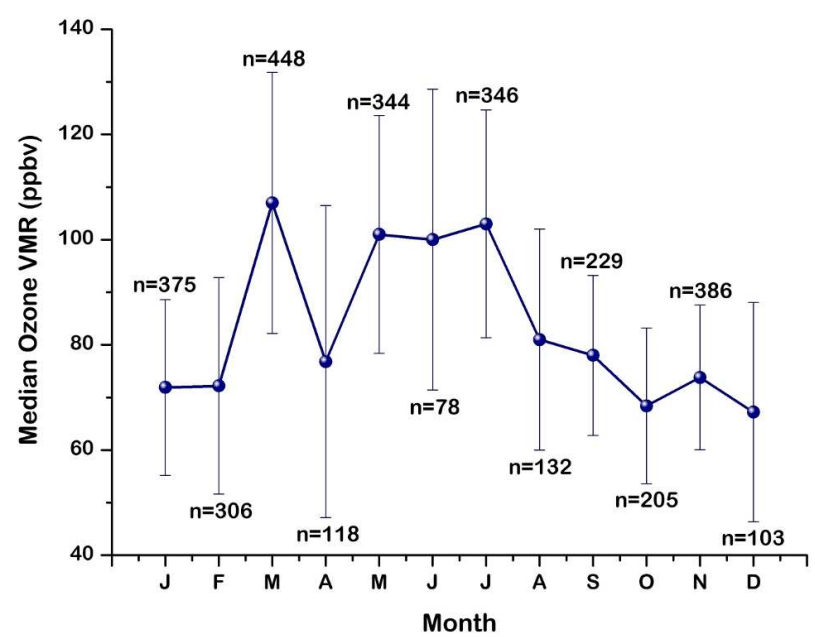

Fig. 4. Monthly median VMR values for $\mathrm{O}_{3}$ in the Northern Hemisphere from all filtered ACE-FTS measurements made in the troposphere during a $4 \mathrm{yr}$ period (2008-2011), without the threshold on HCN applied. The error bars represent the standard deviation for the set of measurements used in the calculation. The number of occultations, $n$, used to calculate each monthly median is reported. The altitude range for the measurements are from $5.5-18.5 \mathrm{~km}$. Elevated $\mathrm{O}_{3}$ VMRs in the spring months correspond to the agricultural practices in Russia and East Asia. The enhanced $\mathrm{O}_{3}$ in the summer months is coincident with boreal wildfire activity.

$\Delta \mathrm{O}_{3} / \Delta \mathrm{CO}$ of approximately 0.03 and 0.11 for fresh biomass burning plumes and aged plumes mixed with urban emissions, respectively. It is not clear whether this enhancement is due to mixing with urban air masses or also due to a suppression of $\mathrm{O}_{3}$ production near the fire source. The sets of age-dependent enhancement ratios calculated in this work were done using only measurements of boreal biomass burning plumes which were identified as coming from a single source. In addition, the measurements made by ACE-FTS are from plumes which have been transported high into the upper troposphere from isolated convection events and/or fireaided pyroconvective updrafts from large forest fires. This reduces the potential interaction with anthropogenic pollution sources due to the likelihood of confinement within the boundary layer, as is the case with the emissions from smaller fires.

Plotted in Fig. 3 are the ACE-FTS VMR profiles for HCN and $\mathrm{O}_{3}$ from the young boreal plume recorded in sunset occultation ss42910. From the HCN profile, we observe that a rapid enhancement in the $\mathrm{HCN}$ concentration occurs below $10.5 \mathrm{~km}$ as the instrument begins to record through the pyrogenic outflow. From within the plume, a markedly decreased value in the $\mathrm{O}_{3}$ VMRs $(\sim 25 \%)$ is observed when compared to the off-plume concentrations recorded from the tropopause at $14.6 \mathrm{~km}$ (value obtained from the DMP for ss42910) down to $10.5 \mathrm{~km}$. The profiles demonstrate that $\mathrm{O}_{3}$ in young plumes is undergoing a destruction process, while
$\mathrm{O}_{3}$ outside of the plume is elevated to values much higher than background levels sampled from clean marine air in the upper troposphere over the North Atlantic during months of minimal fire activity in the Northern Hemisphere $(\sim 55 \mathrm{ppb}$, Jaeglé et al., 1999). Both species correlate highly with CO, demonstrating that they are pyrogenic in nature. The high negative correlation for $\mathrm{O}_{3}$ indicates that a destruction process is occurring in the young plume. This is corroborated by the enhancement ratios with respect to $\mathrm{CO}$ calculated for both $\mathrm{HCN}$ and $\mathrm{O}_{3}$, which are $(4.26 \pm 0.66) \times 10^{-3}$ and $-0.70 \pm 0.27$, respectively. It should be noted that due to the small number of data points available from an individual occultation, the enhancement ratios reported in Fig. 3 were not calculated using the same restrictions used for the sets of age-dependent enhancement ratios in Table 1, where only data corresponding to measurements $\geq 0.30 \mathrm{ppbv}$ were used. The enhancement ratios in Fig. 3 were obtained using the data recorded from $10.5-7.5 \mathrm{~km}$, which correspond to the measurements from within the plume even though the HCN VMRs for the data recorded at $10.5-9.5 \mathrm{~km}$ are below 0.30 ppbv.

The profiles in Fig. 3 and the results for $\mathrm{O}_{3}$ in Table 1 are reminiscent of similar findings made by Tereszchuk et al. (2011), where a continuous plume outflow originating from the tropical forests in Amazonia on 29 October 2004 was measured by ACE-FTS. The off-plume VMRs for $\mathrm{O}_{3}$ were much higher than those recorded in the plume, but remained lower than the off-plume values recorded nearby at similar latitudes during the same corresponding time period. In addition, these off-plume VMRs were elevated high above the typical background values for $\mathrm{O}_{3}$. Both scenarios would indicate that biomass burning is producing $\mathrm{O}_{3}$, but as a secondary pyrogenic species formed in aged plumes. It was noted by Dupont et al. (2012) that the young plumes from Asian wildfires measured during the ARCTAS-A campaign contained the precursors to react in the troposphere and produce $\mathrm{O}_{3}$, but because plume sampling occurred just after emission, sufficient time was not allowed for $\mathrm{O}_{3}$ production to occur. These observations for $\mathrm{O}_{3}$ production were confirmed during BORTAS from the analysis of ozone photochemistry observed by the FAAM BAe-146 research aircraft (Parrington et al., 2013).

Since the only other major source of tropospheric $\mathrm{O}_{3}$ is from anthropogenic pollution ( $\mathrm{smog}$ ), which is primarily restricted to the lower troposphere (ground level, boundary layar), a simplistic way to demonstrate that boreal biomass burning plumes are producing $\mathrm{O}_{3}$ is to analyse the annual trend for $\mathrm{O}_{3}$ in the middle to upper troposphere in the Northern Hemisphere and observe whether increases in $\mathrm{O}_{3}$ VMR values coincide with the lofted emissions originating from fire activity. As indicated in the introduction of this work, ACE-FTS measurements have a bias such that occultations only measure down to $5 \mathrm{~km}$ above the Earth's surface, thus limiting ACE-FTS measurements to the middle to upper troposphere. Figure 4 plots the monthly median VMRs for $\mathrm{O}_{3}$ 

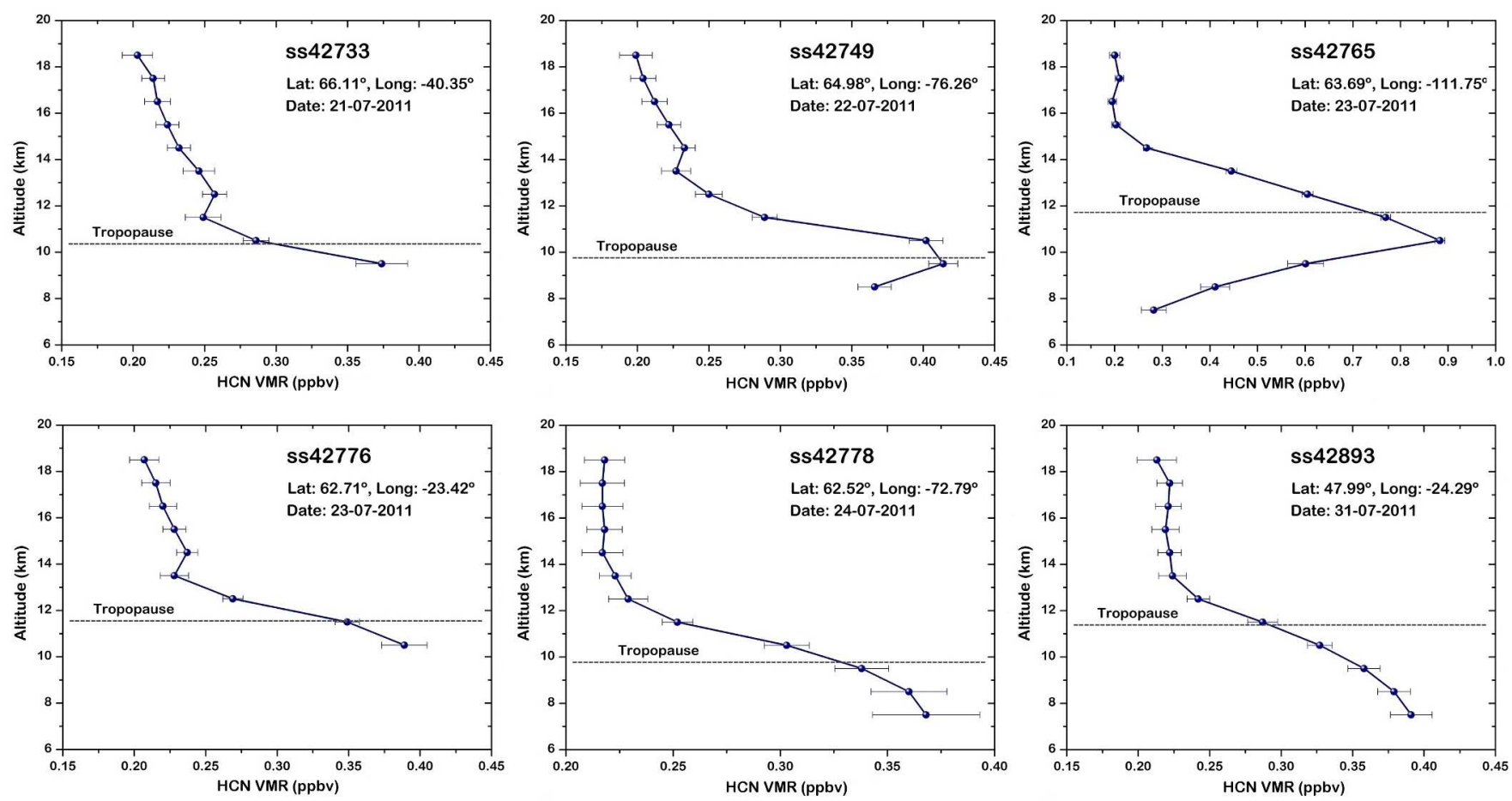

Fig. 5. HCN VMR profiles from occultations containing measurements of young $(<2$ days in age $)$ Canadian boreal biomass burning plumes recorded during the BORTAS campaign. Each demonstrates the intrusion of pyrogenic emissions into the stratosphere, suggesting that fireaided convective processes may cause perturbations that result in the stratosphere-troposphere exchange of air masses.

in the Northern Hemisphere from all filtered ACE-FTS measurements, without the threshold on HCN applied, made in the troposphere during a $4 \mathrm{yr}$ period (2008-2011). The error bars represent the calculated 1-sigma standard deviation for the set of measurements. As expected, $\mathrm{O}_{3}$ VMRs are at their lowest during the winter months when biomass burning activity is minimal, but elevated values are clearly noted during the spring and summer months. By using the MODIS fire and IASI CO data, the geographic locations for the sources of the biomass burning can be deduced. The enhancement of $\mathrm{O}_{3}$ in March is coincident with large pyrogenic outflows resulting from slash and burn activity and the burning of crop residues in the southeastern region of mainland China, Indochina, and India. The median VMR declines in April and, once again, become elevated in May through to August. The burning activity occurring in May is also attributed to the burning of crop residues, but predominantly from the area in the arable regions along the southern border of Russia. The elevation in $\mathrm{O}_{3}$ in June, July, and August corresponds primarily to boreal forest fires. Figure 4 indicates that there is a correlation between fire activity in the Northern Hemisphere and $\mathrm{O}_{3}$ production in the free troposphere. This would indicate that the elevated, off-plume values observed in ss42910 are due to boreal fire activity prior to the time of measurement and that $\mathrm{O}_{3}$ production occurs in the pyrogenic emissions from aged plumes since the net production of $\mathrm{O}_{3}$ in nascent and young plumes is negative.

\section{Stratosphere-troposphere exchange due to pyroconvective updrafts}

Are aged plumes or young plumes which have interacted with anthropogenic pollution the only source of $\mathrm{O}_{3}$ ? Dupont et al. (2012) made the observation that, in addition to photochemical production of $\mathrm{O}_{3}$ from precursors formed in the plumes, exchange between the stratosphere and the troposphere was a major factor influencing $\mathrm{O}_{3}$ concentrations in plumes measured during ARCTAS. Biomass burning emissions can be injected into the upper troposphere by isolated convection that is not fire related as well as by pyroconvection; are fire-aided convective processes capable of perturbing the tropopause and permitting $\mathrm{O}_{3}$ from stratospheric air into the free troposphere? During the BORTAS campaign, ACE-FTS made measurements of boreal plumes over Canada, where the pyrogenic outflow had been lofted to altitudes where plumes demonstrated intrusion into the stratosphere. Figure 5 shows the HCN VMR profiles from six randomly selected occultations containing measurements of young $(<2$ days in age) plumes obtained during BORTAS, where enhanced concentrations of HCN are observed at and above the tropopause. Again, the thermal tropopause 

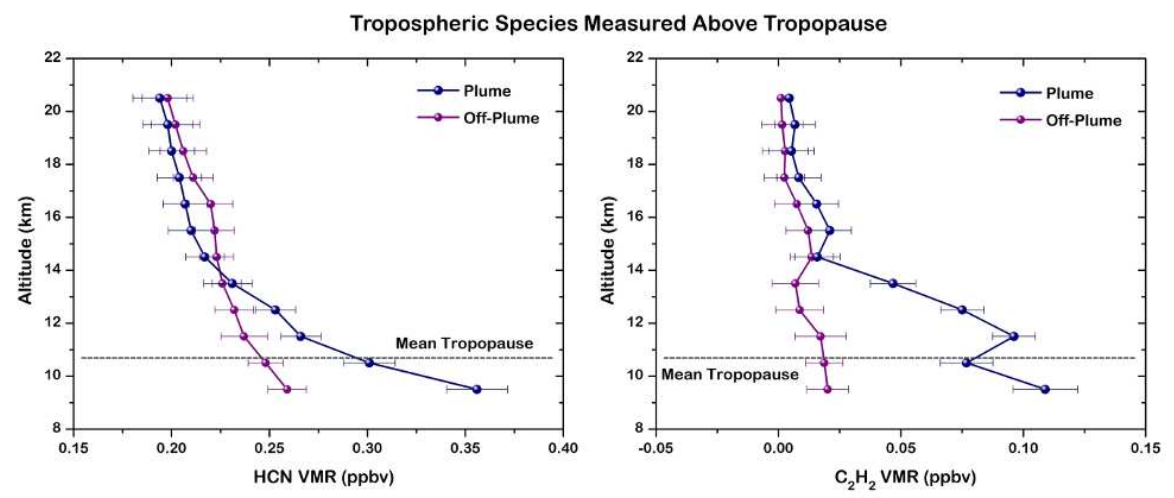

Stratospheric Species Measured Below Tropopause
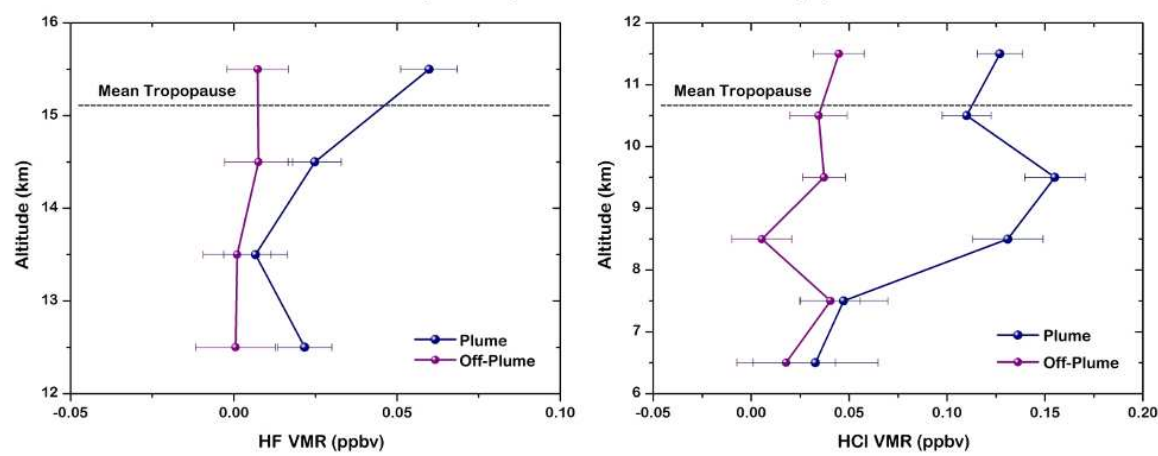

Fig. 6. Observation of strat.-trop. mixing in Canadian boreal biomass burning plumes. Comparison of the average of 15 VMR profiles of pyrogenic species $\left(\mathrm{HCN}, \mathrm{C}_{2} \mathrm{H}_{2}\right)$ measured in the stratosphere to an equivalent number off-plume measurements made over Canada during the summer (JJA) of 2008-2011. Also compared are the on- and off-plume average measurements tropospheric VMRs of stratospheric species $(\mathrm{HF}, \mathrm{HCl})$ observed in the troposphere using the same occultations. Occultations containing measurements of biomass burning plumes contain elevated VMRs of $\mathrm{HCN}$ and $\mathrm{C}_{2} \mathrm{H}_{2}$ in the stratosphere and enhanced $\mathrm{HF}$ and $\mathrm{HCl}$ in the troposphere, which give an indication of the exchange of air masses between the troposphere and stratosphere likely due to perturbation caused by fire-aided convective processes.

heights were obtained from derived meteorological products (DMPs) that are produced using the ACE-FTS version 3.0 dataset (Manney et al., 2007).

An inspection of the HCN VMR profiles of the boreal biomass burning plumes recorded over Canada during the summer months (JJA) of 2008-2011 show that a number of measurements containing enhancements in $\mathrm{HCN}$ above the tropopause were observed. They are more prevalent in occultations made in high latitudes where the tropopause is closer to ground level. Injection of pyrogenic emissions into the stratosphere would be facilitated for instances of boreal fire activity occurring in the northerly latitudes of Siberia, Alaska, and Northern Canada. Given the evidence for the occurrence of stratospheric intrusion of biomass burning plumes due to fire-aided convective processes, the question remains whether or not these intrusions cause perturbations in which stratospheric air masses are drawn into the free troposphere, potentially mixing stratospheric $\mathrm{O}_{3}$ with the plume emissions, which may account for the sporadic nature of the presence of elevated $\mathrm{O}_{3}$ in young boreal biomass burning plumes observed in prior measurement campaigns.
If perturbations are indeed occurring, there should be evidence of enhancements in the VMRs of pyrogenic species originating from these lofted plumes in the stratosphere when compared to off-plume measurements made over Canada during the same time period. Conversely, it is expected that there would be elevations in the VMRs of typically stratospheric species in the upper troposphere as stratospheric air masses are being forced down into the troposphere as a result of these pyroconvective updrafts. Figure 6 contains the VMR profiles for two pyrogenic species $\left(\mathrm{C}_{2} \mathrm{H}_{2}\right.$ and $\left.\mathrm{HCN}\right)$ measured in the stratosphere and for two stratospheric species ( $\mathrm{HF}$ and $\mathrm{HCl})$ in the troposphere. These profiles were obtained by averaging the profiles measured from above and below the tropopause accordingly for 15 occultations containing measurements of young ( $<2$ days in age) boreal biomass burning plumes recorded over Canada during the summer months (JJA) of 2008-2011, which demonstrated in their individual HCN concentration profiles an intrusion of the biomass burning plume into the stratosphere. These averaged profiles are then compared to the averaged profiles of the same number of off-plume measurements taken over Canada during the same time period. We clearly observe in Fig. 6 an 


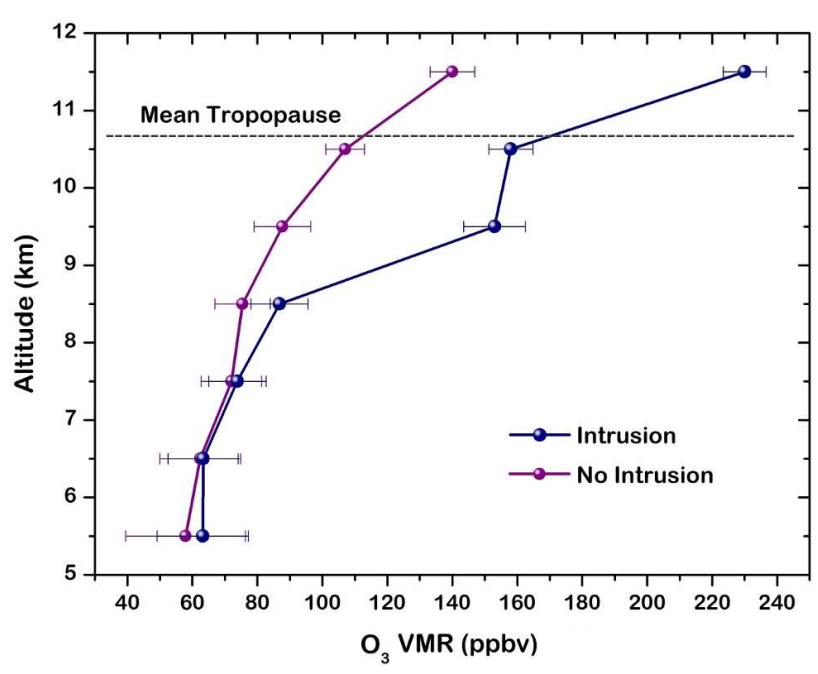

Fig. 7. Observation of stratospheric $\mathrm{O}_{3}$ in the free troposphere. Comparison of the averaged $\mathrm{O}_{3}$ VMR profiles recorded from below the tropopause for the six young boreal plumes in Fig. 5, which demonstrated intrusion of pyrogenic emissions into the stratosphere, to the averaged profiles of six plumes where their HCN profiles indicate that the pyrogenic outflow was confined to the troposphere. The VMR profile obtained from the plumes recorded in Fig. 5 clearly indicates large increases in $\mathrm{O}_{3}$ relative to the profile where intrusion has not occurred. This strongly suggests that stratospheric air is being forced into the free troposphere and that the origin of the $\mathrm{O}_{3}$ in these young plumes is from the stratosphere.

enhancement in the profiles for the pyrogenic species in the stratosphere when compared to the averaged off-plume measurements and, similarly, enhancements are observed in the concentrations of $\mathrm{HF}$ and $\mathrm{HCl}$ in the plume measurements made within the troposphere, indicating that pyroconvection and/or fire-aided convective processes are causing an exchange in air masses between the troposphere and stratosphere. To demonstrate that $\mathrm{O}_{3}$ from the stratosphere is indeed being injected into the troposphere, the $\mathrm{O}_{3}$ profiles from data recorded below the tropopause from the six occultations reported in Fig. 5 were averaged together and compared to measurements of biomass burning plumes of the same relative age from a similar number of occultations recorded during the BORTAS campaign, where the HCN profiles show maximum values in the middle troposphere and do not show evidence of intrusion into the stratosphere. Upon comparison we observe in Fig. 7 that the enhancements in the VMR values of $\mathrm{O}_{3}$ are quite evident in the profile where stratospheric intrusion of the biomass burning plume is occurring, strongly suggesting that stratosphere-troposphere exchange is taking place and injecting stratospheric air through the tropopause and mixing with the pyrogenic outflows from these boreal fires.

\section{Conclusions}

Measurements of trace species from biomass burning plumes were made using ACE-FTS. An extensive set of 14 molecules - $\mathrm{CH}_{3} \mathrm{OH}, \mathrm{C}_{2} \mathrm{H}_{2}, \mathrm{C}_{2} \mathrm{H}_{6}, \mathrm{C}_{3} \mathrm{H}_{6} \mathrm{O}, \mathrm{CO}, \mathrm{HCN}$, $\mathrm{HCOOH}, \mathrm{HNO}_{3}, \mathrm{H}_{2} \mathrm{CO}, \mathrm{NO}, \mathrm{NO}_{2}, \mathrm{OCS}, \mathrm{O}_{3}$, and PAN - have been analysed to generate sets of age-dependent enhancement ratios calculated from the pyrogenic emissions from boreal fires originating from both North America (Canada, Alaska) and Siberia for a period of up to 7 days. These enhancement ratios can be used to test the predictions of CTMs used to study the evolution of pyrogenic species in the long-range transport of boreal biomass burning plumes in the middle and upper troposphere. The enhancement ratios derived for the pyrogenic species measured in the emissions from the boreal fires exhibit the expected trend where the ratio values for the shorter lived primary pyrogenic species decrease over time as these species are oxidized primarily by the $\mathrm{OH}$ radical, as the plume ages and values for longer lived species such as $\mathrm{HCN}$ and $\mathrm{C}_{2} \mathrm{H}_{6}$ remain relatively unchanged. Increasing negative values are observed for the oxidant species, including $\mathrm{O}_{3}$, indicating that these species are undergoing a destruction process in the plume as it ages such that concentrations of the oxidant species have dropped below their off-plume values. Even though decreases in $\mathrm{O}_{3}$ concentrations are observed within the plumes, the off-plume concentrations of $\mathrm{O}_{3}$ measured during the height of boreal forest fire activity in Canada are elevated above typical background values. Median concentrations of $\mathrm{O}_{3}$ in the middle and upper troposphere of the Northern Hemisphere demonstrate a strong seasonality where enhancements in $\mathrm{O}_{3}$ are coincident with biomass burning activity, indicating that biomass burning is generating $\mathrm{O}_{3}$, but as a secondary pyrogenic species in aged plumes. Results from previous measurement campaigns have indicated that elevated concentrations of $\mathrm{O}_{3}$ and positive molar ratios of $\Delta \mathrm{O}_{3} / \Delta \mathrm{CO}$ have been observed in young boreal biomass burning plumes, but the presence of $\mathrm{O}_{3}$ in the young plumes has been attributed to pollution effects where the pyrogenic outflows have mixed with either local urban $\mathrm{NO}_{\mathrm{x}}$ emissions or pyrogenic emissions from the long-range transport of older plumes. The results from this work have demonstrated that an additional source of $\mathrm{O}_{3}$ measured in young boreal plumes may be attributed to the occurrence of stratosphere-troposphere exchange due to the pyroconvective updrafts from large fires. Perturbations caused by the lofted emissions in these fireaided convective processes can potentially result in the intrusion of stratospheric air masses into the free troposphere and subsequent mixing of stratospheric $\mathrm{O}_{3}$ into these pyrogenic outflows. 
Acknowledgements. The ACE mission is funded primarily by the Canadian Space Agency. The authors would like to thank the Natural Environment Research Council of the United Kingdom for funding K. A. Tereszchuk through grant NE/F017391/1 and the Wild Fund for their support of G. González Abad. The authors would like to further acknowledge the LATMOS research group for providing the Level 2 IASI CO data. IASI has been developed and built under the responsibility of the Centre National d'Etudes Spatiales (CNES, France). It is flown onboard the MetOp satellites as part of the Eumetsat Polar System.

Edited by: S. Matthiesen

\section{References}

Akagi, S. K., Yokelson, R. J., Wiedinmyer, C., Alvarado, M. J., Reid, J. S., Karl, T., Crounse, J. D., and Wennberg, P. O.: Emission factors for open and domestic biomass burning for use in atmospheric models, Atmos. Chem. Phys., 11, 4039-4072, doi:10.5194/acp-11-4039-2011, 2011.

Allen, G., Remedios, J. J., Newnham, D. A., Smith, K. M., and Monks, P. S.: Improved mid-infrared cross-sections for peroxyacetyl nitrate (PAN) vapour, Atmos. Chem. Phys., 5, 47-56, doi:10.5194/acp-5-47-2005, 2005.

Alvarado, M. J., Logan, J. A., Mao, J., Apel, E., Riemer, D., Blake, D., Cohen, R. C., Min, K.-E., Perring, A. E., Browne, E. C., Wooldridge, P. J., Diskin, G. S., Sachse, G. W., Fuelberg, H., Sessions, W. R., Harrigan, D. L., Huey, G., Liao, J., Case-Hanks, A., Jimenez, J. L., Cubison, M. J., Vay, S. A., Weinheimer, A. J., Knapp, D. J., Montzka, D. D., Flocke, F. M., Pollack, I. B., Wennberg, P. O., Kurten, A., Crounse, J., Clair, J. M. St., Wisthaler, A., Mikoviny, T., Yantosca, R. M., Carouge, C. C., and Le Sager, P.: Nitrogen oxides and PAN in plumes from boreal fires during ARCTAS-B and their impact on ozone: an integrated analysis of aircraft and satellite observations, Atmos. Chem. Phys., 10, 9739-9760, doi:10.5194/acp-10-9739-2010, 2010.

Andreae, M. O. and Merlet, P.: Emission of trace gases and aerosols from biomass burning, G. Biogeochem. Cy., 15, 955-966, 2001.

Bernath, P. F., McElroy, C. T., Abrams, M. C., Boone, C. D., Butler, M., Camy-Peyret, C., Carleer, M., Clerbaux, C., Coheur, P.-F., Colin, R., DeCola, P., DeMazière, M., Drummond, J. R., Dufour, D., Evans, W. F. J., Fast, H., Fussen, D., Gilbert, K., Jennings, D. E., Llewellyn, E. J., Lowe, R. P., Mahieu, E., McConnell, J. C., McHugh, M., McLeod, S. D., Michaud, R., Midwinter, C., Nassar, R., Nichitiu, F., Nowlan, C., Rinsland, C. P., Rochon, Y. J., Rowlands, N., Semeniuk, K., Simon, P., Skelton, R., Sloan, J. J., Soucy, M.-A., Strong, K., Tremblay, P., Turnbull, D., Walker, K.A., Walkty, I., Wardle, D. A., Wehrle, V., Zander, R., and Zou, J.: Atmospheric Chemistry Experiment (ACE): Mission overview, Geophys. Res. Lett., 32, L15S01, doi:10.1029/2005GL022386, 2005.

Boone, C. D., Nassar, R., Walker, K. A., Rochon, Y., McLeod, S. D., Rinsland, C. P., and Bernath, P. F.: Retrievals for the atmospheric chemistry experiment Fourier-transform spectrometer, Appl. Optics, 44, 7218-7231, 2005.

Clerbaux, C., Boynard, A., Clarisse, L., George, M., Hadji-Lazaro, J., Herbin, H., Hurtmans, D., Pommier, M., Razavi, A., Turquety, S., Wespes, C., and Coheur, P.-F.: Monitoring of atmospheric composition using the thermal infrared IASI/MetOp sounder, At- mos. Chem. Phys., 9, 6041-6054, doi:10.5194/acp-9-6041-2009, 2009.

Coheur, P.-F., Herbin, H., Clerbaux, C., Hurtmans, D., Wespes, C., Carleer, M., Turquety, S., Rinsland, C. P., Remedios, J., Hauglustaine, D., Boone, C. D., and Bernath, P. F.: ACE-FTS observation of a young biomass burning plume: first reported measurements of $\mathrm{C}_{2} \mathrm{H}_{4}, \mathrm{C}_{3} \mathrm{H}_{6} \mathrm{O}, \mathrm{H}_{2} \mathrm{CO}$ and PAN by infrared occultation from space, Atmos. Chem. Phys., 7, 5437-5446, doi:10.5194/acp-75437-2007, 2007.

Coheur, P.-F., Clarisse, L., Turquety, S., Hurtmans, D., and Clerbaux, C.: IASI measurements of reactive trace species in biomass burning plumes, Atmos. Chem. Phys., 9, 5655-5667, doi:10.5194/acp-9-5655-2009, 2009.

Crutzen, P. J., Height, L. E., Krasnec, J. P., Pollock, W. P., and Seiler, W.: Biomass burning as a source of atmospheric gases $\mathrm{CO}, \mathrm{H}_{2}$, $\mathrm{N}_{2} \mathrm{O}, \mathrm{NO}, \mathrm{CH}_{3} \mathrm{Cl}$, and COS, Nature, 282, 253-256, 1979.

Crutzen, P. J. and Andreae, M. O.: Biomass burning in the tropics: Impact on atmospheric chemistry and biogeochemical cycles, Science, 250, 1669-1678, 1990.

Draxler, R. R., and Rolph, G. D.: HYSPLIT (HYbrid Single-Particle Lagrangian Integrated Trajectory) Model, NOAA Air Resources Laboratory, Silver Spring, MD, available at: http://www.arl.noaa. gov/ready/hysplit4.html (last access: October 2012), 2003.

Dupont, R., Pierce, B., Worden, J., Hair, J., Fenn, M., Hamer, P., Natarajan, M., Schaack, T., Lenzen, A., Apel, E., Dibb, J., Diskin, G., Huey, G., Weinheimer, A., Kondo, Y., and Knapp, D.: Attribution and evolution of ozone from Asian wild fires using satellite and aircraft measurements during the ARCTAS campaign, Atmos. Chem. Phys., 12, 169-188, doi:10.5194/acp-12169-2012, 2012.

Fiedler, V., Arnold, F., Ludmann, S., Minikin, A., Hamburger, T., Pirjola, L., Dörnbrack, A., and Schlager, H.: African biomass burning plumes over the Atlantic: aircraft based measurements and implications for $\mathrm{H}_{2} \mathrm{SO}_{4}$ and $\mathrm{HNO}_{3}$ mediated smoke particle activation, Atmos. Chem. Phys., 11, 3211-3225, doi:10.5194/acp-11-3211-2011, 2011.

George, M., Clerbaux, C., Hurtmans, D., Turquety, S., Coheur, P.F., Pommier, M., Hadji-Lazaro, J., Edwards, D. P., Worden, H., Luo, M., Rinsland, C., and McMillan, W.: Carbon monoxide distributions from the IASI/METOP mission: evaluation with other space-borne remote sensors, Atmos. Chem. Phys., 9, 8317-8330, doi:10.5194/acp-9-8317-2009, 2009.

Glatthor, N., von Clarmann, T., Stiller, G. P., Funke, B., Koukouli, M. E., Fischer, H., Grabowski, U., Höpfner, M., Kellmann, S., and Linden, A.: Large-scale upper tropospheric pollution observed by MIPAS HCN and $\mathrm{C}_{2} \mathrm{H}_{6}$ global distributions, Atmos. Chem. Phys., 9, 9619-9634, doi:10.5194/acp-9-9619-2009, 2009.

Hobbs, P. V., Sinha, P., Yokelson, R. J., Christian, T. J., Blake, D. R., Gao, S., Kirchstetter, T. W., Novakov, T., and Pilewskie, P.: Evolution of gases and particles from a savanna fire in South Africa, J. Geophys. Res., 108, 8485, doi:10.1029/2002JD002352, 2003.

Hornbrook, R. S., Blake, D. R., Diskin, G. S., Fried, A., Fuelberg, H. E., Meinardi, S., Mikoviny, T., Richter, D., Sachse, G. W., Vay, S. A., Walega, J., Weibring, P., Weinheimer, A. J., Wiedinmyer, C., Wisthaler, A., Hills, A., Riemer, D. D., and Apel, E. C.: Observations of nonmethane organic compounds during ARCTAS - Part 1: Biomass burning emissions and plume enhancements, Atmos. Chem. Phys., 11, 11103-11130, doi:10.5194/acp- 
11-11103-2011, 2011.

Jaeglé, L., Jacob, D. J., Brune, W. H., Faloona, I. C., Tan, D., Kondo, Y., Sachse, G. W., Anderson, B., Gregory, G. L., Vay, S., Singh, H. B., Blake, D. R., and Shetter, R.: Ozone production in the upper troposphere and the influence of aircraft during SONEX: Approach of $\mathrm{NO}_{\mathrm{x}}$-saturated conditions, Geophys. Res. Lett., 26, 3081-3084, 1999.

Jaffe, D. A. and Wigder, N. L.: Ozone production from wildfires: A Critical Review, Atmos. Environ., 51, 1-10, 2012.

Lefer, B. L., Talbot R. W., Harriss, R. H., Bradshaw, J. D., Sandholm, S. T., Olson, J. O., Sachse, G.W., Collins, J., Shipham, M. A., Blake, D. R., Klemm, K. I., Klemm, O., Gorzelska, K., and Barrick, J.: Enhancement of acidic gases in biomass burning impacted air masses over Canada, J. Geophys. Res., 99, 1721-1737, 1994.

Li, Q., Jacob, D. J., Yantosca, R. M., Heald, C. L., Singh, H. B., Koike, M., Zhao, Y., Sachse, G. W., and Streets, D. G.: A global three-dimensional model analysis of the atmospheric budgets of $\mathrm{HCN}$ and $\mathrm{CH}_{3} \mathrm{CN}$ : Constraints from aircraft and ground measurements, J. Geophys. Res., 108, 8827, doi:10.1029/2002JD003075, 2003.

Manney, G. L., Daffer, W. H., Zawodny, J. M., Bernath, P. F., Hoppel, K. W.,Walker, K. A., Knosp, B. W., Boone, C., Remsberg, E. E., Santee, M. L., Harvey, V. L., Pawson, S., Jackson, D. R., Deaver, L., McElroy, C. T., McLinden, C. A., Drummond, J. R., Pumphrey, H. C., Lambert, A., Schwartz, M. J., Froidevaux, L., McLeod, S., Takacs, L. L., Suarez, M. J., Trepte, C. R., Cuddy, D. C., Livesey, N. J., Harwood, R. S., and Waters, J. W. : Solar occultation satellite data and derived meteorological products: sampling issues and comparisons with Aura MLS, J. Geophys. Res., 112, D24S50, doi:10.1029/2007JD008709, 2007.

Palmer, P. I., Parrington, M., Lee, J. D., Lewis, A. C., Rickard, A. R., Bernath, P. F., Duck, T. J., Waugh, D. L., Tarasick, D. W., Andrews, S., Aruffo, E., Bailey, L. J., Barrett, E., Bauguitte, S. J.B., Curry, K. R., Di Carlo, P., Chisholm, L., Dan, L., Forster, G., Franklin, J. E., Gibson, M. D., Griffin, D., Helmig, D., Hopkins, J. R., Hopper, J. T., Jenkin, M. E., Kindred, D., Kliever, J., Le Breton, M., Matthiesen, S., Maurice, M., Moller, S., Moore, D. P., Oram, D. E., O'Shea, S. J., Christopher Owen, R., Pagniello, C. M. L. S., Pawson, S., Percival, C. J., Pierce, J. R., Punjabi, S., Purvis, R. M., Remedios, J. J., Rotermund, K. M., Sakamoto, K. M., da Silva, A. M., Strawbridge, K. B., Strong, K., Taylor, J., Trigwell, R., Tereszchuk, K. A., Walker, K. A., Weaver, D., Whaley, C., and Young, J. C.: Quantifying the impact of BOReal forest fires on Tropospheric oxidants over the Atlantic using Aircraft and Satellites (BORTAS) experiment: design, execution and science overview, Atmos. Chem. Phys. Discuss., 13, 4127-4181, doi:10.5194/acpd-13-4127-2013, 2013.

Parrington, M., Palmer, P. I., Lewis, A. C., Lee, J. D., Rickard, A. R., Di Carlo, P., Taylor, J. W., Hopkins, J. R., Punjabi, S., Oram, D. E., Forster, G., Aruffo, E., Moller, S. J., Bauguitte, S. J.-B., Allan, J. D., Coe, H., and Leigh, R. J.: Ozone photochemistry in boreal biomass burning plumes, Atmos. Chem. Phys. Discuss., 13, 1795-1853, doi:10.5194/acpd-13-1795-2013, 2013.

Rinsland, C. P., Dufour, G., Boone, C. D., Bernath, P. F., and Chiou, L.: Atmospheric Chemistry Experiment (ACE) measurements of elevated Southern Hemisphere upper tropospheric $\mathrm{CO}, \mathrm{C}_{2} \mathrm{H}_{6}$, $\mathrm{HCN}$, and $\mathrm{C}_{2} \mathrm{H}_{2}$ mixing ratios from biomass burning emissions and long-range transport, Geophys. Res. Lett., 32, L20803,
doi:10.1029/2005GL024214, 2005.

Rinsland, C. P., Dufour, G., Boone, C. D., Bernath, P. F., Chiou, L., Coheur, P. -F., Turquety, S., and Clerbaux, C.: Satellite boreal measurements over Alaska and Canada during June-July 2004: Simultaneous measurements of upper tropospheric $\mathrm{CO}$, $\mathrm{C}_{2} \mathrm{H}_{6}, \mathrm{HCN}, \mathrm{CH}_{3} \mathrm{Cl}, \mathrm{CH}_{4}, \mathrm{C}_{2} \mathrm{H}_{2}, \mathrm{CH}_{3} \mathrm{OH}, \mathrm{HCOOH}, \mathrm{OCS}$, and $\mathrm{SF}_{6}$ mixing ratios, Global Biogeochem. Cy., 21, GB3008, doi:10.1029/2006GB002795, 2007.

Simpson, I. J., Akagi, S. K., Barletta, B., Blake, N. J., Choi, Y., Diskin, G. S., Fried, A., Fuelberg, H. E., Meinardi, S., Rowland, F. S., Vay, S. A., Weinheimer, A. J., Wennberg, P. O., Wiebring, P., Wisthaler, A., Yang, M., Yokelson, R. J., and Blake, D. R.: Boreal forest fire emissions in fresh Canadian smoke plumes: $\mathrm{C}_{1}-\mathrm{C}_{10}$ volatile organic compounds (VOCs), $\mathrm{CO}_{2}, \mathrm{CO}, \mathrm{NO}_{2}$, NO, HCN and CH3CN, Atmos. Chem. Phys., 11, 6445-6463, doi:10.5194/acp-11-6445-2011, 2011.

Singh, H. B., Salas, L., Herlth, D., Kolyer, R., Czech, E., Viezee, W., Li, Q., Jacob, D. J., Blake, D., Sachse, G., Harward, C. N., Fuelberg, H., Kiley, C. M., Zhao, Y., and Kondo, Y.: In situ measurements of $\mathrm{HCN}$ and $\mathrm{CH}_{3} \mathrm{CN}$ over the Pacific Ocean: Sources, sinks, and budgets, J. Geophys. Res., 108, 8795, doi:10.1029/2002JD003006, 2003.

Singh, H. B., Anderson, B. E., Brune, W. H., Cai, C., Cohen, R. C., Crawford, J. H., Cubison, M. J., Czech, E. P., Emmons, L., Fuelberg, H. E., Huey, G., Jacob, D. J, Jimenez, J. L., Kaduwela, A., Kondo, Y., Mao, J., Olson, J. R., Sachse, G. W., and Vay, S. A., Weinheimer, A., Wennberg, P. O., Wisthalerm, A., the ARCTAS Science Team: Pollution influences on atmospheric composition and chemistry at high northern latitudes: Boreal and California forest fire emissions, Atmos. Environ., 44, 4553-4564, 2010.

Stubenrauch, C. J., Cros, S., Guignard, A., and Lamquin, N.: A 6-year global cloud climatology from the Atmospheric InfraRed Sounder AIRS and a statistical analysis in synergy with CALIPSO and CloudSat, Atmos. Chem. Phys., 10, 7197-7214, doi:10.5194/acp-10-7197-2010, 2010.

Torres, O., Chen, Z., Jethva, H., Ahn, C., Freitas, S. R., and Bhartia, P. K.: OMI and MODIS observations of the anomalous 20082009 Southern Hemisphere biomass burning seasons, Atmos. Chem. Phys., 10, 3505-3513, doi:10.5194/acp-10-3505-2010, 2010.

Tereszchuk, K. A., González Abad, G., Clerbaux, C., Hurtmans, D., Coheur, P.-F., and Bernath, P. F.: ACE-FTS measurements of trace species in the characterization of biomass burning plumes, Atmos. Chem. Phys., 11, 12169-12179, doi:10.5194/acp-1112169-2011, 2011.

Turquety, S., Hurtmans, D., Hadji-Lazaro, J., Coheur, P.-F., Clerbaux, C., Josset, D., and Tsamalis, C.: Tracking the emission and transport of pollution from wildfires using the IASI CO retrievals: analysis of the summer 2007 Greek fires, Atmos. Chem. Phys., 9, 4897-4913, doi:10.5194/acp-9-4897-2009, 2009.

Yokelson, R. J., Crounse, J. D., DeCarlo, P. F., Karl, T., Urbanski, S., Atlas, E., Campos, T., Shinozuka, Y., Kapustin, V., Clarke, A. D., Weinheimer, A., Knapp, D. J., Montzka, D. D., Holloway, J., Weibring, P., Flocke, F., Zheng, W., Toohey, D., Wennberg, P. O., Wiedinmyer, C., Mauldin, L., Fried, A., Richter, D., Walega, J., Jimenez, J. L., Adachi, K., Buseck, P. R., Hall, S. R., and Shetter, R.: Emissions from biomass burning in the Yucatan, Atmos. Chem. Phys., 9, 5785-5812, doi:10.5194/acp-9-5785-2009, 2009. 